\title{
SUBJECTS OF THE EMPRESS. WIDER CONTEXT OF REGIONAL HISTORY EDUCATION ON EAST PRUSSIA AND IDENTITY PROCESSES IN CONTEMPORARY KALININGRAD OBLAST
}

\begin{abstract}
Political, economic and social changes brought about by the dissolution of the Soviet Union have had a significant impact on Kaliningrad Oblast, the empire's westernmost territory of geostrategic importance. Formerly belonging to the German province of East Prussia, the region was meant to become Sovietised completely. The end of the Cold War led to a complete bankruptcy of such policies. At the turn of the $80 \mathrm{~s}$ and $90 \mathrm{~s}$ the emergence of a grass-roots interest in the officially forbidden parts of the Oblast's history made the question of the relation between its pre-war and postwar past up-to-date. Its topicality was strengthened after the 2005-06 commemorations of founding the city of Königsberg and Kaliningrad Oblast, in which both central and regional authorities were heavily involved. This paper aims at identifying how elements of the history of East Prussia have been selected, interpreted and incorporated into the regional history education course books in contemporary Kaliningrad Oblast. It argues that the growing criticism of the course books' contents has been related to Russia's domestic situation since the 2012 presidential election and the tensions with the West after 2014. Both events have hastened the process of forming and cementing the so-called new Russian conservatism which has had a growing influence on the Baltic semiexclave.
\end{abstract}

Key words: Kaliningrad Oblast; Russian Federation; Soviet Union; East Prussia; history education; regional identity; national identity
MILOSZ JANUSZ ZIELIŃSKI SWPS Uniwersytet Humanistycznospołeczny, Warszawa E-mail: milosz@miloszzielinski.pl

CITATION: Zieliński, M. J. (2018) Subjects of the Empress. Wider Context of Regional History Education on East Prussia and Identity Processes in Contemporary Kaliningrad Oblast.

Sprawy Narodowościowe. Seria nowa, 2018(50). https://doi.org/10.11649/sn.1629

This work was supported by the National Science Centre (grant number UMO-2012/06/A/HS3/00266). No competing interests have been declared.

This is an Open Access article distributed under the terms of the Creative Commons Attribution 3.0 PL License (creativecommons.org/licenses/by/3.0/pl/), which permits redistribution, commercial and non-commercial, provided that the article is properly cited. (C) The Author(s) 2018.

Publisher: Institute of Slavic Studies, Polish Academy of Sciences 


\section{PODDANI CESARZOWEJ. SZEROKI KONTEKST REGIONALNEJ EDUKACJI HISTORYCZNEJ NA TEMAT PRUS WSCHODNICH A PROCESY TOŻSAMOŚCIOWE WE WSPÓLCZESNYM OBWODZIE KALININGRADZKIM}

\section{Streszczenie}

Zmiany polityczne, gospodarcze i społeczne spowodowane rozpadem Związku Sowieckiego wywarty głęboki wpływ na obwód kaliningradzki, najdalej wysunięty na zachód obszar imperium o dużym znaczeniu geostrategicznym. Obwód, wcześniej wchodzący w skład niemieckich Prus Wschodnich, miał zostać całkowicie zsowietyzowany. Koniec zimnej wojny doprowadził do bankructwa takiej polityki. Na przełomie lat osiemdziesiątych i dziewięćdziesiątych pojawienie się oddolnego zainteresowania oficjalnie zakazanymi częściami historii obwodu spowodowało, że pytanie o stosunek między jego przeszłością przedwojenną i powojenną stało się bardzo aktualne. Ten stan został wzmocniony po uroczystościach związanych z założeniem miasta Królewiec i obwodu kaliningradzkiego w latach 2005-06, w które zaangażowały się zarówno władze centralne, jak i regionalne. Niniejszy artykuł ma na celu prześledzenie, w jaki sposób elementy historii Prus Wschodnich zostały wybrane, zinterpretowane i włączone do podręczników poświęconych historii regionu we współczesnym obwodzie kaliningradzkim. Autor argumentuje, że rosnąca krytyka treści podręczników związana jest z sytuacją wewnętrzną Rosji po wyborach prezydenckich w 2012 roku oraz rosnącymi napięciami w stosunkach z państwami zachodnimi. Obydwa wydarzenia przyspieszyły proces kształtowania i krzepnięcia tak zwanego nowego rosyjskiego projektu konserwatywnego, który wywiera coraz większy wpływ na bałtycką półeksklawę.

Stowa kluczow e: obwód kaliningradzki; Federacja Rosyjska; Związek Sowiecki; Prusy Wschodnie; nauczanie historii; tożsamość regionalna; tożsamość narodowa

\section{INTRODUCTION}

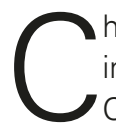

hanges brought about by the dissolution of the Soviet Union have had a significant impact on Kaliningrad Oblast, the empire's westernmost part incorporated in 1945. Created as a rudimentary negation of its pre-war predecessor, Germany's East Prussia, the region was meant to become sovietised in every possible aspect. In particular, its seven-century-long history was to be rewritten from the perspective of MarxismLeninism and Russo-Slavic imperialism, discrediting East Prussia as a militarist, aggressive and anti-Slavic political entity, the destruction of which was an act of historical justice. This narrative was intended to become deeply rooted into the mindset of the new inhabitants of the Oblast who came from various parts of the Soviet Union. They were very often too young to remember the pre-October Revolution period, which additionally intensified the impact of the new approach (Костяшов, 1996, p. 87; Сологубов, 2012, p. 41).

The end of the Cold War led to a complete bankruptcy of such policies. The emergence of a spontaneous, grass-roots interest in alternative visions of the Oblast's history, initially in very limited circles of regional intelligentsia and nomenclature, made the question of relations between the pre-war and post-war past of the region increasingly important (Дементьев, 2014). The real boom took place when information technologies started to spread in the city of Kaliningrad and, to some extent, in other parts of the Oblast. It resulted in a growing number of ordinary citizens taking part in the discussion on what East Prussia means on the one hand, and what it should mean on the other hand for contemporary Kaliningraders. Together with academicians, politicians and NGO activists they 
started asking questions to what extent the 'East Prussianness' could be compatible with the 'Sovietness' and the 'Russianness' on regional, local and individual levels.

It is now visible that this discussion has become a part of a broader, Russian-wide discourse on the reinterpretation of both the Russian and the Soviet history, also in terms of shaping the national and regional history education. In this article I take a close look at how the 1871-1945 period of the history of East Prussia (from the unification of Germany until the defeat of the Third Reich in World War Two) has been portrayed in the regional history course books in Kaliningrad Oblast. Their contents have been put into both the regional context and the developments in Russia since 2012: the emergence of the socalled new conservatism and the sharp deterioration of Russia's relations with the West after the annexation of Crimea and breaking out of the war in Eastern Ukraine. I have sought to explain how criticism of the course books was influenced by these changes affecting Russia in general and Kaliningrad Oblast in particular.

In order to achieve the above-mentioned goals I have used a variety of research material. The background knowledge on the history of East Prussia and Kaliningrad Oblast was provided by books by C. Clark (Clark, 2009), Ю. В. Костяшов (Костяшов, 2009), A. Kossert, R. Traba (Traba, 2005) and A. Sakson (Sakson, 2011). Works by O. Sezneva (Sezneva, 2007, 2010, 2013) and И. О. Дементьев (Дементьев, 2014) gave a specific look at how attitudes towards the pre-war past evolved in Kaliningrad Oblast. The central part of the article revolves around the regional history course books written by Г. В. Кретинин, А. П. Клемешев, Ю. В. Костяшов and Г. М. Федоров for grades from 6 to 11 (Клемешев, Костяшов, \& Федоров, 2007; Кретинин, 2007a, 2007b).

In order to confront the contents of the course books with the overall context of internal developments in Russia since the turn of 2011 and 2012, I have used a number of articles from the presidential campaign published by $\mathrm{V}$. Putin in various Russian media outlets (Путин 2012a; Путин 2012b; Путин 2012c) and studies analysing them, such as those on the 'new conservatism' originating from the Warsaw-based Centre for Eastern Studies (Rodkiewicz \& Rogoża, 2015; Rogoża, 2013). Criticism of their contents has predominantly been present on regional web portals, but also in the Russian-wide press, such as "Литературная газета".

\section{HOW EAST PRUSSIA (RE)APPEARED IN KALININGRAD OBLAST}

When World War Two came to an end East Prussia was in ruins. As the very first province of the pre-1937 Germany that the Red Army entered, it suffered not only from regular military actions, but also from the aftermath events. The vendetta of the Soviet soldiers was stoke up by the authorities. In the wartime and the post-war Soviet propaganda East Prussia was depicted as, for instance, 'the lair of the fascist beast' (Костяшов, 2003, p. 11) and 'German Empire's watchdog in the East' (Костяшов, 2003, p. 14). Such an aggressive way of portraying the province had calamitous effects on civilians who did not escape before the Red Army as well as on the material culture.

Approximately 100,000 Germans-less than 10 per cent of the pre-war population, remained in the province until 1950. They were resettled to the Soviet occupational zone of Germany (Костяшов, 1996, р. 83). New inhabitants came mostly from the Russian, Belarusian and Ukrainian Soviet Republics. They were predominantly young and did not re- 
member the times prior to 1917. Speaking in terms of civilizational experience their new home was completely different from what they were used to. For authorities in Moscow the Oblast was thus a perfect place for creating Homo Sovieticus (Heller, 1988).

Interest in discovering the pre-Soviet roots of the region appeared already in the second generation of the Kaliningrad inhabitants and grew alongside the scope of liberty in the country (Дементьев, 2014, pp. 183-184). During perestroika it took the form of hobbyists-diggers who semi-legally excavated old pieces of cutlery, crockery or bottles (Sezneva, 2007). Nevertheless, a deeper interest in the past was shared only by a limited circle of regional intelligentsia and a few members of the nomenclature (Дементьев, 2014, pp. 188-192).

The situation changed following the dissolution of the Soviet Union (Хоппе, 2005, p. 199). After the initial period of economic downturn and serious social challenges the notion of the pre-war history started to find its place in the everyday life of Kaliningraders. It even gained a nationwide attention in 2005-2006 alongside the official celebrations of $700^{\text {th }}$ Anniversary of Königsberg and $70^{\text {th }}$ Anniversary of Kaliningrad. President Vladimir Putin met with Chancellor Gerhard Schröder and President Jacques Chirac in Kaliningrad, where he emphasized the European roots of the city and supported the idea of rebuilding its historic centre (Siegień, 2016, p. 116).

The 2005-06 events marked the moment when the notion of East Prussia evolved from a hobby of the few to an inseparable part of a broader public debate on how it should be rediscovered and interpreted on a regional level. The once forbidden 'Prussian spirit' quickly became a full-featured element of the main quotidian topic on various levels. Gradually a growing number of institutions, starting from the governor's office and other regional governmental bodies, became involved in shaping the 'East Prussian part' of the political, economic and social agenda in contemporary Kaliningrad Oblast.

The captivation of the pre-war history topic was further strengthened by a rapid development of information technologies. Regional portals, discussion fora and social networks became platforms for intensive dialogue between individuals. Favourable climate for speaking about pre-1945 times openly and publicly became a trigger for the idea of introducing a regional history course in the secondary and high school education system in the Oblast.

\section{ZAPADNYI KRAI: THE REGIONAL HISTORY COURSE BOOKS AND INITIAL CRITICISM}

The course on the history of the Western Land (западный край) or Western Russia (Западная Россия) was created by a group of academicians from the Immanuel Kant Russian State University: ${ }^{1}$ Кретинин, Г. В. (classes 6-9), А. П. Клемешев, Ю. В. Костяшов, Г. М. Федоров (classes 10-11). ${ }^{2}$ The outline of the course was presented in the document entitled the Programme of Public Education on Regional History (Программа общего образования по истории края; Кретинин \& Строганова 2006). It served as a basis of three course books: from prehistoric times to the $18^{\text {th }}$ century; until the beginning of World War Two; since 1939-1941 until 2006. The last part tells the story of East Prussia being conquered by the Red Army in 1944-45, Soviet Kaliningrad Oblast being emerged and

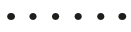

\footnotetext{
1 The University was founded in 1967 under the name of Kaliningrad State University. In 2005 it was renamed to Immanuel Kant Russian State University by President Putin and Chancellor Schröder. In 2010 President Medvedev renamed it to Immanuel Kant Baltic Federal University.

2 In this article they will be jointly referred to as 'authors'.
} 
the way developments in the region shaped after the dissolution of the Soviet Union. The testing period of the course was launched in September 2006 in 36 schools attended by 2,250 students (Корвин, 2007).

By large, while discussing the Russo-Prussian relations in the 19th century, authors highlight their positive aspects, such as Prussia's neutrality during the Crimean War, which helped Russia limit its isolation in Europe. St. Petersburg returned this favour when it did not oppose the unification of Germany under the reign of the Hohenzollern (Кретинин, 2007b, pp. 139-142). In the overall complexity of Russo-German relations East Prussia played the role of a marketplace and was an area of relatively high level of freedom where various political ideas were free to emerge. Authors give an example of socialist activists whose actions contributed to preparing the ground for the 1905 revolution in Russia. Although they were persecuted by German law enforcement bodies, they could count on a fair trial and successfully defend their views (Кретинин, 2007b, pp. 139-140). Thus, intelligentsia felt comfortable in the city of Königsberg where atmosphere of free thought prevailed over the militaristic Prussian government (Кретинин, 2007b, p. 157).

Much complicated reasons for the outbreak of war in 1914 were explained very briefly. Authors took laconic notes of deterioration of the Russo-German relations in 18911894 (Кретинин, 2007b, pp. 141-142). When the conflict finally started in 1914 military actions in East Prussia were interrelated with those on the Western Front. The Russian army entered the province in order to fulfil its duties towards France (Кретинин, 2007b, p. 156). The quick assault on East Prussia in summer of 1914 is described as a strategic mistake resulting in Russia's defeat in the First Battle of the Masuria Lakes (Кретинин, 2007b, pp. 165-166). Authors even write that "the credit has to be given to the German commandment" (надо отдать должное германскому командованию) for the way that liberating East Prussia was carried out (Кретинин, 2007b, p. 172). At the same time authors note the importance of the 1914 campaign in the German nationalist symbolic of the interwar period. They give the Tannenberg Memorial as an example (Tannenberg Denkmal; Кретинин, 2007b, p. 166).

The course books touch upon the behaviour of Russian forces in East Prussia. Authors acknowledge that there might have been incidental atrocities committed towards civilians, yet they underline that the majority of Russian troops behaved orderly. To strengthen this statement authors present testimonies of German citizens who not only confirm this correct stance but also oppose other points of view overemphasizing the alleged bestiality of Russians on East Prussian soil (Кретинин, 2007b, pp. 166-169). Authors emphasize that the question of relations between armed forces and civilians during wartime objectively belongs to the list of the most difficult ones and that "East Prussia was no exception" (Кретинин, 2007b, p. 169).

Authors seek to highlight the universal atrocity affecting the mankind in general, regardless of ethnic or political differences. Thousands of casualties of the first mass-scale conflict in history of both German and Russian nationalities were buried on numerous sites in East Prussia. The course books show the example of a Russo-German graveyard in the village of Lasdehnen (contemporary Kranoznamensk) which has been preserved until the present day (Кретинин, 2007b, p. 163). In Kaliningrad Oblast there are also sites where exclusively Russian soldiers were buried (Кретинин, 2007b, p. 173).

Consequences of the war are described as being of both real and symbolic nature. The latter is related to the formal end of the Kingdom of Prussia (which in the course books is referred to as the Duchy of Prussia-Герцогство Пруссия). Authors write that East Prussia as 
a separate entity was emblematic of "Germany's claims towards the Baltic states, Poland, [as well as] Russian, Belarusian and Ukrainian lands" (Кретинин, 2007b, p. 179). It did not, however, cancel the claims themselves even when the Weimar Republic was established.

The main challenges that East Prussia and the government in Berlin had to face pertained to stabilise the political and economic situation of the province. Thanks to intensified efforts and considerable financial support, authors write, it was finally achieved (Кретинин, 2007b, pp. 185-187). It was also possible thanks to economic cooperation between Germany and Soviet Russia after the Treaty of Rapallo in 1922 when bilateral diplomatic relations were established. Soviet economic presence in East Prussia was visible notably through the East German Trade Fair (the Ostmesse; Восточная ярмарка) in Königsberg (Кретинин, 2007b, pp. 188-190).

The end of the 1930s, however, was marked with increased tensions in Europe which resulted in another world war. Authors of the course books start the wartime story of East Prussia from 1941, i.e. from the beginning of the so-called Great Patriotic War. They also mention, however, that the province took part in the war campaign against Poland in September 1939 (Клемешев et al., 2007, pp. 3-4). Although East Prussia is described as place d'armes (плацдарм) of Germany's aggression against the Soviet Union, the war seemed to be distant for the inhabitants of the province for three years, with the exception of rare air bombings of the Soviet aviation (Кретинин, 2007b, p. 200).

The third part of the course books starts from describing military actions in East Prussia in 1944-1945 (with a short introduction referring to September 1939), devoting much space to Soviet war heroes: General Ivan D. Chernyakhovsky, Marshall Konstantin K. Rokossovsky, as well as lower rank heroes Alexey I. Tazayev and Sergey I. Gusev, who were killed in action in the province. Particular attention is given to the siege of Königsberg, led by General Alexandr M. Vasilevski (Клемешев et al., 2007, pp. 13-18).

The end of the war was followed by the introduction of the Soviet military administration in East Prussia. Authors show a considerable deal of criticism towards its actions. They touch upon the controversial topic of the so-called bounty hunters (трофейные команды) who did great harm to the regional economy, impeding its reconstruction. As it is explained in the course books, such actions were tolerated due to uncertain future of the territories conquered by the Red Army.

The course books also encompass the facts about the lives of that part of the German population that did not flee their homes, consisting mostly of women, children and elders. Authors acknowledge harsh conditions inhabitants had to withstand, including constant problems with provisioning and forced labour, for instance, repairing roads and dismantling ruins. Although their situation was difficult, Soviet authorities allowed them to perform religious practices in churches which was forbidden for Orthodox newcomers (Клемешев et al., 2007, pp. 24-25).

In general, the course books tell the story of 1944-1945 and the first post-war years in a very objective and unbiased way. While accepting the geopolitical consequences of the war they do not omit negative aspects of the new political, economic and social circumstances. Students reading the book are likely to understand that history is never either just black or white, no matter how trivial such a remark would sound. Authors embark from regional rather than national history narrative. They accept the fact that until 1945 East Prussia's administrative language was German. One might wonder that is why they consequently use German toponyms (written in Cyrillic) throughout the pre-1945 chapters and do not mention their contemporary Russian equivalents. 
The internal situation of the post-Yeltsin Russia has been increasingly determined by policies formed on the central level. This phenomenon has reversed the inertia of decentralisation and partial regionalisation observed since the last years of existence of the Soviet Union (Marciniak, 2001). Back then some regions gained considerable factual autonomy due to an insignificant control exercised by Moscow. When Vladimir Putin came to power the role of the vast majority of regional authorities quickly changed from moderately independent players to plain executors of the Kremlin-shaped policies. It has had serious consequences on all subjects of the Russian Federation and cannot be explained briefly without making major simplifications.

During the 2012 presidential campaign Vladimir Putin published seven articles on different aspects of Russia's present and future, out of which at least three tackled history and culture related issues (Путин, 2012a, 2012b, 2012c). Putin sketched the desired path of Russia's development and the set of values that it should abide by. He underlined the positive role of the strong state apparatus which had been deeply rooted in the Russian political culture. He also stressed the need for gradual changes and opposed radical moves (Rodkiewicz \& Rogoża, 2015, pp. 8-9). Later on, Putin conceptualised and refined his points, paving the way for the so-called new conservative project. He suggested that Russia is a distinctive civilizational centre and should pursue independent political and cultural policies, in particular within the post-Soviet space (Путин, 2012a).

Putin's words were soon forged into concrete actions, notably, to further strengthen soft power instruments that Russia had started to develop couple of years earlier. This tendency was envisaged in the 2013 Russia's foreign policy concept ("Concept of the Foreign Policy", 2013). In order to strengthen the Russian statehood and its ties with Russians living abroad, an important role was given to the Russian Orthodox Church, traditionally closely linked with the authorities, and the Russkiy Mir Foundation established in 2007.

The second game-changer was the outbreak of the so-called Revolution of Dignity in Ukraine and the events that followed-annexation of Crimea and war in Donbas. They resulted in sharp deterioration of Russo-Western relations, including sanctions imposed by, among others, the European Union and the United States. It coincided with the economic slowdown in Russia caused by structural macroeconomic shortcomings, such as corruption and mismanagement. Together with the growing atmosphere of the 'new Cold War', the Kremlin turned to well-known tools in order to gain popular support, such as the myth of a besieged fortress (осаждённая крепость). According to it, for centuries Russia has been surrounded by enemies who have tried to weaken and humiliate the country. Citizens of contemporary Russia should once again unite around their leader to repel the aggressors (Колесников, 2015).

Confrontation invoked by the events of 2012-2014 became visible in Kaliningrad Oblast, although with some delay in many important areas of socio-political life of the semiexclave. At first, economic downturn was stronger in the region than in Russia in average. This created a theoretical danger that Kaliningraders might be willing to show their discontent by taking to the streets similar to 2009 and 2010, which finally did not take place. For a number of reasons they either supported Kremlin's policies or remained passive.

In Moscow's eyes geostrategic importance of the Oblast prevailed over its cooperation potential towards its immediate neighbourhood. Its military potential was signifi- 
cantly strengthened (Wiśniewska, Domańska, Strzelecki, Żochowski, Wilk, \& Menkiszak, 2016). Altogether, the region once again was placed at the frontline of political or any other kind of confrontation with the West.

Managing the crisis in the Oblast became of significant importance for central authorities in view of the 2018 FIFA World Championship, which will be co-hosted by Kaliningrad. Ensuring smooth preparations for the event was the main reason for major shifts in the regional administration. Governor Nikolay Tsukanov was temporarily replaced by a silovik Georgi Zinichev. Later on, Zinichev yielded for Anton Alikhanov, a young technocrat whose main task was to stabilise economic situation of the region and ensure swift implementation of Kremlin's policies. His first months in office confirmed this reasoning.

Both new governors limited regional authorities' engagement in issues connected with the pre-war legacy of the Oblast, such as the reconstruction of the historical centre of Kaliningrad and preservation of pre-1945 buildings. In fact, they narrowed down the official historical agenda to the elements directly corresponding to the 'new Russian conservatism'. Alikhanov took an active part in numerous events commemorating Russia's presence in East Prussia; for instance, during the Seven Years' War of 1756-1763, when Russian troops came to the province both as an enemy and as an ally. In August 2017, Alikhanov unveiled a monument devoted to General Field Marshall Pyotr Rumyantsev (Сумарокова, 2017). Two weeks later he opened a renewed monument of the battle of GrossJägersdorf (Гросс-Егерсдорф; contemporary village of Междуречье). During the ceremony he said: "Here a whole host of Russian war commanders has written their names into the history of this soil with golden letters"3 ("Антон Алиханов открыл", 2017).

\section{CRITICISM OF THE COURSE BOOKS}

The course books were met with significant criticism the instant they were introduced. Main objections pertained to the allegedly pro-German perspective from which the authors told the history of East Prussia. In the books it was acknowledged that throughout seven centuries of its existence East Prussia was closely linked with the German culture, language and politico-legal reality. Thus, critics argued: "The introduction of the History of Western Russia as a regional component in the current time frame (34 hours a year) will inevitably provide an incentive to promote separatism and a pro-German orientation among the students" 4 (Корвин, 2007).

It was, however, not until 2014-2015 that the criticism gained on strength. Tatyana Shabayeva expressed her reservations towards the course books in "Литературная газета" in early 2015. While avoiding politically motivated arguments, Shabayeva wrote:

Please read [in the course book for grades 8-9]: "The beginning of the war [East Prussian people] welcomed. The war quickly moved eastward from the borders of the Reich. There seemed to be no threat to the province. The bombings of the Soviet aviation were a sad reminder of the war." Who should be compared to a young man who learned the history of the same people who "welcomed the beginning of the war with satisfaction"? Will he be

Здесь целая плеяда российских военных начальников вписала золотыми буквами свои имена в историю этой земли.

4 Внедрение „Истории Западной России” в качестве регионального компонента в нынешнем объёме (34 часа в год) неизбежно будет способствовать воспитанию у учащихся сепаратизма и прогерманской ориентации 
able to feel the connection, the continuation between him and the Soviet aviation, which so unpleasantly destroys the peace of the province?

The authors of "The History of Western Russia" are apparently not worried. The subject goes to the textbook for grades 10-11: "The war came unexpectedly. On 17 August 1944, the Soviet forces reached the border between the USSR and Germany near Schirwindt [contemporary village of Kutuzovo]." The children of the Kaliningrad region are again suggested to feel as if they were on the German side. Yet it was for the Germans in 1944 that "the war came unexpectedly" (which is a bit strange in the face of "nasty bombardments carried out by the Soviet aviation") (Шабаева, 2015). ${ }^{5}$

At that time some voices spoke about the alleged process of Königsbergization (which might also be referred to as Germanisation) of Kaliningrad Oblast as a (geo)political rather than cultural phenomenon (Выползов, 2016). It is significant that they were formulated shortly after the sharp deterioration of the Russo-Western relations, suggesting that exploration of the pre-war past had been inspired by external forces intending to weaken the "Russianness" of the Oblast. These voices devoted little attention to formulating a positive counter-agenda.

The new wave of criticism reached its peak in mid-2017 when the tenth anniversary of introducing the regional history course gave a pretext for their deeper assessment. In order to present main arguments raised, I have used the round table dedicated to the course books, which took place in July 2017, as well as some public statements made by prominent figures in Kaliningrad Oblast.

At the round table, Georgiy Biryukov, protoiereus of the Russian Orthodox Church in Kaliningrad Oblast, described the course and the course books as "categorically harmful". He referred to the books in terms of civilizational differences between the East Prussian and Soviet/Russian periods of the region's history, as well as to the books lacking political and legal explanations why the Soviet Union conquered East Prussia. He underlined that, in particular, the authors did not include references to:

- Churchill's conversation with Soviet Ambassador Ivan Mayski in 1941, in which the former proposed to split Germany and separate East Prussia;

- the Tehran and Yalta conferences where the fate of Königsberg was discussed;

- the law of the Union Control Council in Germany of 1947 "On the Elimination of the Prussian State" ("История Западной России способствует", 2017).

Similar arguments were expressed by Vladimir Shulgin of the Russian National Line: ${ }^{6}$

We warned as early as in 2006 that the textbooks "The History of Western Russia" did not meet the national interests of Russia. This course, instead of Russian [both русская and российская история] history, tells the history of Germany and it does so based on a limited

\section{- •. •}

Вчитайтесь: "Начало войны население встретило с удовлетворением. Боевые действия вскоре переместились от границ рейха на восток. Казалось, провинции ничто не угрожает. Неприятным напоминанием о войне были редкие бомбардировки советской авиации». С кем должен соотносить себя молодой человек, если до сих пор он изучал историю того самого населения, которое «начало войны встретило с удовлетворением»? Сможет ли он ощутить связь, преемственность с советской авиацией, которая так неприятно тревожила спокойствие провинции? Авторов "Истории Западной России» это, кажется, не заботит. Тема перетекает в учебник 10-11-х классов (авторы-А.П. Клемешев, Ю.В. Костяшов, Г.М. Фёдоров): «Война пришла неожиданно. Советские войска в районе Ширвиндта 17 августа 1944 года вышли на границу между СССР и Германией». Снова детям Калининградской области предлагается почувствовать себя на стороне Германии. Это для немцев в 1944 году “война пришла неожиданно» (что немного странно после «неприятных бомбардировок советской авиации»).

6 Русская народная линия (Russian National Line) is an "Orthodox informational agency" which was founded in St. Petersburg in 2010 after some members of the "Russian Line" (founded in 2008) left the organisation. The Russian National Line represents ethno- and religion-nationalist point of view on current developments in Russia and its close neighbourhood. It is a fierce opponent of the presence of Western civilisation in the Orthodox world. 
range of sources, which does not include those referring to the millennial war of the West against the Byzantine Civilisation. This course was written by foreign history specialists and one geographer. There was not a single Russian history specialist. Even this fact is an indicator of what the point of view of the authors of the course was. If this course is not corrected, it will continue to have an impact not only on schoolchildren and students, but also on those who are getting ready to become officers and defenders of the Motherland ("Если не станем противостоять в Калининграде", 2017). ${ }^{7}$

Maxim Makarov, President of the Russian Community of Kaliningrad Oblast Regional $\mathrm{NGO},{ }^{8}$ pointed to the relation between the ethno-national and civic identity of Russians. According to him, the former should be strengthened in order to stop the process of blurring and weakening the latter, also through the course books which has a negative impact on all of those attending schools in the Oblast ${ }^{9}$ ("Если не станем противостоять в Калининграде", 2017).

Among those taking part in the discussion was Andrey Klemeshev, rector of the Federal Baltic University in Kaliningrad, who is often referred to as the editor of the whole series of the course books by his critics. ${ }^{10}$ In 2017 he admitted that the current course should be replaced by a new one that will reflect the reality better. In particular, it should take into consideration the post-war (and, one might suspect, post-Cold War) geopolitics. Klemeshev underlined that the whole programme of the regional history was created very quickly during a difficult period. Nowadays, while the new programme is being developed, other events and processes should be stressed in the next generation of course books ("Андрей Клемешев: Учебник", 2017).

One might wonder what is meant by "other events and processes". An indication of that has been given by actions taken by regional government officials at least since 2016. They mostly revolve around traces of the Russian and Soviet presence in East Prussia before 1944-45. In particular, they are related to the military actions during the Seven Years' War, the Napoleonic Wars, as well as the World War One. For example, during the first of the above-mentioned conflicts all of East Prussia was conquered by Russian troops. It was then that Immanuel Kant and other citizens of Königsberg swore allegiance to Empress Elisabeth.

\section{CONCLUSION}

For a number of years the regional history course taught in schools of Kaliningrad Oblast were met with just a moderate criticism. Arguments of its anti-Russian nature were raised by a limited circle of institutions and individuals, usually belonging to radical circles.

7 Мы ещё в 2006 году предостерегали, что учебники «История западной России» не отвечают национальным интересам России. Этот курс вместо русской, российской истории рассматривает историю немецкую, причём на ограниченном круге источников, который не включает себя источники, говорящие о тысячелетней войне Запада с Византийской цивилизацией. Этот курс писали специалисты по зарубежной истории и один географ. Нет ни одного учёного по отечественной истории. Даже этот факт - показатель ориентации авторов курса. Если этот курс не исправить, он и дальше будет оказывать воздействие не только на школьников и студентов, но и на тех, кто готовится стать офицерами, защитниками Родины.

8 Regional NGO Russian Community of Kaliningrad Oblast (Региональная общественная организация «Русская община Калининградской области») was registered only in July 2015 which alone ties the organisation with new developments on Russian political and social scene after 2014.

9 Преподавание курса "История западной России» в нынешнем виде размывает этнонациональную идентичность русских людей, обучающихся в калининградских школах, что приводит к ослаблению их общегражданской российской идентичности.

10 In fact, Klemeshev only co-authored the last part of the series 
For numerous reasons it did not lie in the interest of the central and regional Russian authorities to stop or control the revival of the East Prussian narrative in the Oblast. In the last two to three years the wave of pessimism has become much stronger. Critics who reprimanded the manner in which the last years of the existence of East Prussia and the foundation of Kaliningrad Oblast were portrayed in the regional history course books have embarked from ideological positions which cannot be understood without placing them into the Russian-wide context.

This can be explained in various ways. After more than a decade-long period of growing interest towards exploring elements of the East Prussian past and attempts to incorporate them into the regional history education, opponents of this process started to voice their concerns openly and frequently. According to them, some parts of the 'East Prussian myth' have come at the expense of the official narrative of the history of the Russian state. Critics have argued that the emergence of the myth and anchoring it into the everyday life of ordinary Kaliningraders has been inspired by actors and events from the outside of the region. It has been strictly related to the domestic developments of Russia, as well as to its international situation.

The new conservative project pursued by the central Russian authorities has gradually transposed into numerous parts of the everyday life of ordinary Russians on regional and local levels. One of the areas of confrontation that the new conservatism suggests is the alleged set of tools that enemies of Russia have at their disposal. The Kremlin does not send direct, specific and topic-oriented directions. It rather cares for setting the stage for lower level actions which would fill it with proper content. This is why this rhetoric has been tailored in order to include regional specifics, such as history, social and economic situation, developmental challenges etc. In the case of Kaliningrad Oblast, its historical background and proximity to the West (the EU and NATO states) make the core of the regional face of the new conservative agenda. The region is believed to be susceptible to the foreign influence which forces the authorities and other institutions close to them to take countermeasures.

The discourse on the pre-war history of Kaliningrad Oblast is peculiar in this regard as it belongs to the dual-use category, depending on the overall climate of the Russo-Western relations. During Tsukanov's term in office the question of regional history was constantly present in the public sphere. It even got envisaged in discussions about concrete projects, such as the reconstruction of the historical centre of Kaliningrad or renovation of a few remaining pieces of pre-war architecture. Mainly because of these actions the Oblast could be perceived as a region close to Europe which looks at its East Prussian (Western) roots and takes care of them for numerous reasons. Among them, economic development probably played the most important role for regional authorities. Although the results of this discussion have so far been meagre, they have unleashed a considerable social potential in various groups of the region's population which became visible in many different spheres.

After the 2012-2014 developments in and around Russia the above-mentioned favourable conditions for exploring the pre-war past of Kaliningrad Oblast came to an end. Changes at the top of the regional administration have depicted that further exploration of the pre-war legacy will not rank high on the new governor's political agenda. On the contrary, the time has come to highlight the Russian and Soviet elements of the history of the Oblast. Not only has it become visible in the new initiatives, but it has also affected the ongoing projects and is likely to affect the existing policies. History education is undoubtedly one of them. 
In this context, it needs to be stated that the course books present a highly unbiased story of how East Prussia existed in pre-1945 Germany. Their authors focus on the province itself rather than on German or Russian nation-state historiographical perspectives. The books tell a neutral story of a region that was subject to, willingly or not, supraregional events and processes. They do not try to suggest that throughout the majority of time East Prussia's existence was harmful to the interests of Russia or the Soviet Union. It was only the World War Two that led to geopolitical changes, but even then East Prussia was merely a passive participant in the aggression planned and put into motion by authorities in Berlin.

One can argue that the lack of blatant "pro-Russianness" or "anti-Westernness" in the course books was easier to accept even five years ago. Along with growing assertiveness of Moscow's foreign policy it became less and less sustainable. When tensions reached their critical point in 2014, the hitherto framework of the Russo-Western cooperation took a strong hit. Since then notions such as the Königsbergization have gained popularity in regional media mostly because they have corresponded to the post-2014 Kremlin-shaped national agenda which has heavily exploited the narrative of a 'besieged fortress' and a civilizational conflict.

Under such circumstances there is little place for presenting the history of a region which objectively is not deeply embedded into the traditionally understood "Russianness". Such a sharp reaction of those opposing the narrative present in the course books also points to the fact that there has been a well-established feeling in the region that the level of cultural, religious and social integration between Kaliningrad Oblast and 'mainland' Russia has to be increased. This feeling is probably shared by the central authorities. From their point of view, such policies serve predominantly geopolitical and geostrategic purpose. Thus, the criticism against the course books is fully in line with the current pace and direction of developments in Russia, although, it is perceived somewhat differently on regional and central levels. Nevertheless, it transposes into similar actions and tools used on the ground, such as engagement of the Russian Orthodox Church and numerous cultural organisations into the work on the ground.

The course books on the pre-1945 history of Kaliningrad Oblast will probably be rewritten as a part of a larger programme encompassing over 40 of such publications Russia-wide. The contents of them, however, will not disappear. The reason for this is that the presence of the pre-war past far exceeds the narrow educational system framework. It will remain one of the main topics in the regional media, as well as in everyday talks and activities of ordinary Kaliningraders. On the other hand, the discussion in the spirit of discovering and understanding the pre-war past in a non-biased and non-politically motivated way will remain being affected by Russia-wide and international circumstances. Where it will bring the debate as a whole is yet to be observed.

\section{BIBLIOGRAPHY}

Clark, C. (2009). Prusy: Powstanie i upadek: 1600-1947. (J. Szkudliński, Trans.). Warszawa: Wydawnictwo Bellona.

Concept of the Foreign Policy of the Russian Federation. Approved by President of the Russian Federation V. Putin on 12 February 2013. (2013). Retrieved July 20, 
2018, from http://www.mid.ru/en/foreign_policy/official_documents/-/asset_publisher/ CptlCkB6BZ29/content/id/122186

Heller, M. (1988). Cogs in the wheel: The formation of Soviet man. New York, NY: Alfred A. Knopf.

Kossert, A. (2009). Prusy Wschodnie: Historia i mit. (B. Ostrowska, Trans.). Warszawa: Wydawnictwo Naukowe Scholar.

Marciniak, W. (2001). Rozgrabione imperium: Upadek Związku Sowieckiego i powstanie Federacji Rosyjskiej. Kraków: Wydawnictwo Arcana.

Rodkiewicz, W., \& Rogoża, J. (2015). Potemkin conservatism: An ideological tool of the Kremlin. Warszawa: Ośrodek Studiów Wschodnich.

Rogoża, J. (2013). Adjustment in Putin's state: Under the banner of conservatism. Retrieved July 20, 2018, from https://www.osw.waw.pl/en/publikacje/analyses/2013-12-18/adjustment-putins-state-under-banner-conservatism

Sakson, A. (2011). Od Kłajpedy do Olsztyna: Współcześni mieszkańcy byłych Prus Wschodnich: Kraj Kłajpedzki, Obwód Kaliningradzki, Warmia i Mazury. Poznań: Instytut Zachodni.

Sezneva, O. (2007). "We have never been German": The economy of digging in Russian Kaliningrad. In C. Calhoun \& R. Sennett (Eds.), Practicing culture (pp. 13-34). London: Routledge.

Sezneva, O. (2010). Modalities of self-understanding, identification and representation in the post-1991 Kaliningrad: A critical view. In S. Berger (Ed.), Kaliningrad in Europe: Perspectives from inside and outside. Lüneburg: Nordost-Institut.

Sezneva, O. (2013). Architecture of descent: Historical reconstructions and the politics of belonging in Kaliningrad, the former Königsberg. Journal of Urban History, 39(4), 767-787. https://doi.org/10.1177/0096144212470095

Siegień, P. (2016). How much Königsberg is in Kaliningrad? New Eastern Europe, 2016(5), 115-122.

Traba, R. (2005). Wschodniopruskość: Tożsamość regionalna i narodowa w kulturze politycznej Niemiec. Poznań: Poznańskie Towarzystwo Przyjaciół Nauk.

Wiśniewska, I., Domańska, M., Strzelecki, J., Żochowski, P., Wilk, A., \& Menkiszak, M. (2016). Kaliningrad Oblast 2016: The society, economy and army. Warsaw: Centre for Eastern Studies.

Андрей Клемешев: Учебник “История Западной России” должен быть заменён. (2017, October 10). Retrieved from http://vesti-kaliningrad.ru/a-klemeshev-o-novom-uchebnike-obistorii/

Антон Алиханов открыл памятный знак павшим при Гросс-Егерсдорфе. (2017, August 30). Retrieved July 20, 2018, from http://ruwest.ru/news/74444/

Бродерзен, П. (2005). “Позови меня тихо по имени...": Кампания переименований в Калининградской области в 1946-1950 гг. в контексте калининградско-московских отношений послевоенного времени. In Балтийский регион в истории России и Европы: Материалы международной научной конференции: Калининград, 29-30 октября 2004 г. Калининград.

Выползов, А. (2016). За “кёнигсбергизацией” Калининграда стоят США. REGNUM. Retrieved July 20, 2018, from https://regnum.ru/news/polit/2160463.html

Дементьев, И. О. (2014). "Что я могу знать?": Формирование дискурсов о прошлом Калининградской области в советский период (конец 1940-х-1980-е годы). Люди и тексты: Исторический альманах, 2014, 175-218. 
"Если не станем противостоять в Калининграде, то начнём терять Россию по кусочкам". (2017). Retrieved July 20, 2018, from http://newsbalt.ru/analytics/2017/07/esli-ne-stanem-protivostoyat-v-kaliningrade-to-nachnem-teryat-rossiya-po-kusochkam/

"История Западной России" способствует росту сепаратизма в Калининграде. (2017). Retrieved July 20, 2018, from https://regnum.ru/news/2298605.html

Клемешев, А. П., Костяшов, Ю. В., \& Федоров, Г. М. (2007). История Западной России: Учебник 10-11 классы. Москва: ЗАО “ОЛМА Медиа Групп".

Колесников, А. (2015, June). Российская идеология после Крыма: Пределы эффективности и мобилизации. Retrieved July 20, 2018, from http://carnegieendowment.org/files/ CMC_Brief_Kolesnikov_June2015_Rus.pdf

Корвин, А. (2007). История Западной России. Retrieved July 20, 2018, from http://samlib. ru/k/korwin_a/zxcds.shtml

Костяшов, Ю. В. (1996). Заселение Калининградской области после Второй мировой войны. In Гуманитарная наука в России: Соросовские лауреаты (Vol. 2, pp. 82-88). Москва: Международный Научный Фонд.

Костяшов, Ю. В. (2003). Изгнание прусского духа: Как формировалось историческое сознание населения Калининградской области в послевоенные годы. Калининград: Издательство Калининградского гос. университета.

Костяшов, Ю. В. (2009). Секретная история Калининградской области. Калининград: Терра Балтика.

Кретинин, Г. В. (2007а). История Западной России: Учебник 6-7 классы. Москва: ЗАО "ОлМА Медиа Групп".

Кретинин, Г. В. (2007b). История Западной России: Учебник 8-9 классы. Москва: ЗАО "ОлМА Медиа Групп".

Кретинин, Г. В., \& Строганова, Н. А. (2006). Программа общего образования по истории края. Калининград: РГУ им. И. Канта.

Путин, В. (2012a, February 27). Россия и меняющийся мир. Московские новости. Retrieved July 20, 2018, from http://www.mn.ru/politics/78738

Путин, В. (2012b, January 23). Россия: Национальный вопрос. Независимая газета. Retrieved July 20, 2018, from http://www.ng.ru/politics/2012-01-23/1_national.html

Путин, В. (2012c, January 16). Россия сосредотачивается - вызовы, на которые мы должны ответить. Известия. Retrieved July 20, 2018, from http://izvestia.ru/news/511884

Сологубов, А. М. (2012). Переселенец как Homo Scientis: Эпистемологический аспект освоения Калининградской области. Вестник БФУ им. И. Канта, 2012(6), 39-46.

Сумарокова, А. (2017, August 19). “Ген.-фельдмарш. Румянцев": В Калининграде появились новая улица и памятник. Retrieved July 20, 2018, from https://www.newkaliningrad.ru/news/community/14598360-gen-feldmarsh-rumyantsev-v-kaliningradepoyavilis-novaya-ulitsa-i-pamyatnik.html

Хоппе, Б. (2005). Кёнигсберг/Калининград в XX в.-фокус современной европейской истории. In В. И. Гальцов (Ed.), Балтийский регион в истории России и Европы (pp. 190199). Калининград: Издательство РГУ им. И. Канта.

Шабаева, Т. (2015, April 8). Родная память и чужое наследие. Литературная газета, 2015(14). Retrieved July 20, 2018, from http://www.lgz.ru/article/-14-6504-8-04-2015/ rodnaya-pamyat-i-chuzhoe-nasledie/

Шендерюк, М. Г. (n.d.). Социальный портрет переселенца. Retrieved from http://gako. name/index.php?publ=132\&razd $=207$ 
Andreĭ Klemeshev: Uchebnik "Istoriia Zapadnoĭ Rossii" dolzhen byt' zamenën. (2017, October 10). Retrieved from http://vesti-kaliningrad.ru/a-klemeshev-o-novom-uchebnikeob-istorii/

Anton Alikhanov otkryl pamiatnyı̆ znak pavshim pri Gross-Egersdorfe. (2017, August 30). Retrieved July 20, 2018, from http://ruwest.ru/news/74444/

Broderzen, P. (2005). "Pozovi menia tikho po imeni...": Kampaniia pereimenovaniī $\vee$ Kaliningradskoĭ oblasti $\vee$ 1946-1950 gg. $\vee$ kontekste kaliningradsko-moskovskikh otnosheniĭ poslevoennogo vremeni. In Baltiīskiĭ region v istorii Rossii i Evropy: Materialy mezhdunarodnoi nauchnoĭ konferentsii: Kaliningrad, 29-30 oktiabria 2004 g. Kaliningrad.

Clark, C. (2009). Prusy: Powstanie i upadek: 1600-1947. Warszawa: Wydawnictwo BelIona.

Concept of the Foreign Policy of the Russian Federation. Approved by President of the Russian Federation V. Putin on 12 February 2013. (2013). Retrieved July 20, 2018, from http://www.mid.ru/en/foreign_policy/official_documents/-/asset_publisher/ CptlCkB6BZ29/content/id/122186

Dement'ev, I. O. (2014). "Chto ia mogu znat'?": Formirovanie diskursov o proshlom Kaliningradskoĭ oblasti v sovetskiĭ period (konets 1940-kh-1980-e gody). Liudi i teksty: Istoricheskil al'manakh, 2014, 175-218.

"Esli ne stanem protivostoiat' v Kaliningrade, to nachnëm teriat; Rossiiu po kusochkam". (2017). Retrieved July 20, 2018, from http://newsbalt.ru/analytics/2017/07/esli-ne-stanem-protivostoyat-v-kaliningrade-to-nachnem-teryat-rossiya-po-kusochkam/

Heller, M. (1988). Cogs in the wheel: The formation of Soviet man. New York, NY: Alfred A. Knopf.

"Istoriia Zapadnoĭ Rossii" sposobstvuet rostu separatizma v Kaliningrade. (2017). Retrieved July 20, 2018, from https://regnum.ru/news/2298605.html

Khoppe, B. (2005). Kënigsberg/Kaliningrad v XX v.-fokus sovremennol evropeǐskoĭ istorii. In V. I. Gal'tsov (Ed.), Baltī̌skiĭ region v istorii Rossii i Evropy (pp. 190-199). Kaliningrad: Izdatel'stvo RGU im. I. Kanta.

Klemeshev, A. P., Kostiashov, I. V., \& Fedorov, G. M. (2007). Istoriia Zapadnoi Rossii: Uchebnik 10-11 klassy. Moskva: ZAO "OLMA Media Grupp".

Kolesnikov, A. (2015, June). Rossiīskaia ideologiia posle Kryma: Predely éffektivnosti i mobilizatsii. Retrieved July 20, 2018, from http://carnegieendowment.org/files/CMC_ Brief_Kolesnikov_June2015_Rus.pdf

Korvin, A. (2007). Istoriia Zapadnoĭ Rossii. Retrieved July 20, 2018, from http://samlib. ru/k/korwin_a/zxcds.shtml

Kossert, A. (2009). Prusy Wschodnie: Historia i mit. Warszawa: Wydawnictwo Naukowe Scholar.

Kostiashov, I. V. (1996). Zaselenie Kaliningradskoĭ oblasti posle Vtoroĭ mirovoĭ voĭny. In Gumanitarnaia nauka v Rossii: Sorosovskie laureaty (Vol. 2, pp. 82-88). Moskva: Mezhdunarodnyĭ Nauchnyı̆ Fond.

Kostiashov, I. V. (2003). Izgnanie prusskogo dukha: Kak formirovalos' istoricheskoe soznanie naseleniia Kaliningradskol oblasti v poslevoennye gody. Kaliningrad: Izdatel'stvo Kaliningradskogo gos. universiteta. 
Kostiashov, I. V. (2009). Sekretnaia istoriia Kaliningradskoi oblasti. Kaliningrad: Terra Baltika.

Kretinin, G. V. (2007a). Istoriia Zapadnoi Rossii: Uchebnik 6-7 klassy. Moskva: ZAO "OLMA Media Grupp".

Kretinin, G. V. (2007b). Istoriia Zapadnoi Rossii: Uchebnik 8-9 klassy. Moskva: ZAO "OLMA Media Grupp".

Kretinin, G. V., \& Stroganova, N. A. (2006). Programma obshchego obrazovaniia po istorii kraia. Kaliningrad: RGU im. I. Kanta.

Marciniak, W. (2001). Rozgrabione imperium: Upadek Związku Sowieckiego i powstanie Federacji Rosyjskiej. Kraków: Wydawnictwo Arcana.

Putin, V. (2012a, February 27). Rossiia i meniaiushchiīsia mir. Moskovskie novosti. Retrieved July 20, 2018, from http://www.mn.ru/politics/78738

Putin, V. (2012b, January 23). Rossiia: Natsional'nyı̆ vopros. Nezavisimaia gazeta. Retrieved July 20, 2018, from http://www.ng.ru/politics/2012-01-23/1_national.html

Putin, V. (2012c, January 16). Rossiia sosredotachivaetsia - vyzovy, na kotorye my dolzhny otvetit'. Izvestiia. Retrieved July 20, 2018, from http://izvestia.ru/news/511884

Rodkiewicz, W., \& Rogoża, J. (2015). Potemkin conservatism: An ideological tool of the Kremlin. Warszawa: Ośrodek Studiów Wschodnich.

Rogoża, J. (2013). Adjustment in Putin's state: Under the banner of conservatism. Retrieved July 20, 2018, from https://www.osw.waw.pl/en/publikacje/analyses/2013-12-18/adjustment-putins-state-under-banner-conservatism

Sakson, A. (2011). Od Kłajpedy do Olsztyna: Współcześni mieszkańcy byłych Prus Wschodnich: Kraj Kłajpedzki, Obwód Kaliningradzki, Warmia i Mazury. Poznań: Instytut Zachodni.

Sezneva, O. (2007). "We have never been German": The economy of digging in Russian Kaliningrad. In C. Calhoun \& R. Sennett (Eds.), Practicing culture (pp. 13-34). London: Routledge.

Sezneva, O. (2010). Modalities of self-understanding, identification and representation in the post-1991 Kaliningrad: A critical view. In S. Berger (Ed.), Kaliningrad in Europe: Perspectives from inside and outside. Lüneburg: Nordost-Institut.

Sezneva, O. (2013). Architecture of descent: Historical reconstructions and the politics of belonging in Kaliningrad, the former Königsberg. Journal of Urban History, 39(4), 767-787. https://doi.org/10.1177/0096144212470095

Shabaeva, T. (2015, April 8). Rodnaia pamia' i chuzhoe nasledie. Literaturnaia gazeta, 2015(14). Retrieved July 20, 2018, from http://www.lgz.ru/article/-14-6504-8-04-2015/ rodnaya-pamyat-i-chuzhoe-nasledie/

Shenderiuk, M. G. (n.d.). Sotsial'nyı̆ portret pereselentsa. Retrieved from http://gako. name/index. php?publ=132\&razd $=207$

Siegień, P. (2016). How much Königsberg is in Kaliningrad? New Eastern Europe, 2016(5), 115-122.

Sologubov, A. M. (2012). Pereselenets kak Homo Scientis: Épistemologicheskiī aspekt osvoeniia Kaliningradskoĭ oblasti. Vestnik BFU im. I. Kanta, 2012(6), 39-46.

Sumarokova, A. (2017, August 19). "Gen.-fel'dmarsh. Rumiantsev": V Kaliningrade poiavilas' novaia ulitsa i pamiatnik. Retrieved July 20, 2018, from https://www.newkaliningrad.ru/news/community/14598360-gen-feldmarsh-rumyantsev-v-kaliningradepoyavilis-novaya-ulitsa-i-pamyatnik.html 
Traba, R. (2005). Wschodniopruskość: Tożsamość regionalna i narodowa w kulturze politycznej Niemiec. Poznań: Poznańskie Towarzystwo Przyjaciół Nauk.

Vypolzov, A. (2016). Za "kënigsbergizatsiě̌" Kaliningrada stoiat SShA. REGNUM. Retrieved July 20, 2018, from https://regnum.ru/news/polit/2160463.html

Wiśniewska, I., Domańska, M., Strzelecki, J., Żochowski, P., Wilk, A., \& Menkiszak, M. (2016). Kaliningrad Oblast 2016: The society, economy and army. Warsaw: Centre for Eastern Studies. 